\title{
Assessing the Safety of Express Bus in Malaysia from Bus Operators' Perspective
}

\author{
Abdul Hadi Azman*, Wong Ting Wea \\ Department of Mechanical and Manufacturing Engineering, Faculty of Engineering and \\ Built Environment, Universiti Kebangsaan Malaysia
}

Abstract Express buses provide cheap and convenient services for long distance travelling. However, the safety aspect of express buses is a primary concern for passengers. The government and the private sector have contributed in improving the safety level of express buses. However, the accident and death rates involving express buses remains at a high level. There is a lack of detailed analysis regarding express bus accidents from the perspective of bus operators. Thus, this study was conducted to identify the causes of express bus accidents, characterize the statistical factors of express bus accidents and evaluate the safety of express buses in Malaysia from the perspectives of bus operators. The methodology consists of a survey conducted among staffs serving express bus operators located at the Terminal Bersepadu Selatan, Kuala Lumpur, Malaysia. The results showed that from bus operators' perspective, road factors are the main contributors to the factors of occurrence of express bus accidents. In conclusion, the statistical characterization of accident causes has been determined and this can contribute in helping the bus operators and the community reduce express bus accidents and increase overall safety.

Keywords: Statistical analysis, non-parametric test, bus accident, express bus safety, SPSS.

\section{Introduction}

*For correspondence: hadi.azman@ukm.edu.my

Received: 22 January 2021

Accepted: 15 October 2021

(C) Copyright Azman. This article is distributed under the terms of the Creative Commons Attribution License, which permits unrestricted use and redistribution provided that the original author and source are credited.
Express bus is an important mode of transport in Malaysia, by providing cheap and convenient services for long distance travelling. Research has shown that in Malaysia, buses are more cost-effective than cars, at RM0.70/person-km for busses and RM 2.05/person-km for cars [1]. Passengers expect comfort, safety, and high-quality service while travelling in express busses [2]. However, high accident rates have become one of the concerns for passengers. The total number of road accidents in Malaysia has increased in from 2014 to 2018, as shown in Figure 1 [3]. According to statistics from the Ministry of Transportation Malaysia, the number of buses involved in road accidents increased from 8,804 in 2015 to 9,462 in 2016 but decreased from 2,204 to 7,258 in 2017. The Department of Roads Safety Malaysia reported that the number of passenger fatalities increased from 186 in 2016 to 199 in 2017 but decreased by 7 to 192 in 2018 [4]. The majority of the statistic is due to express bus accidents, which causes a large number of injuries and casualties. In 2018, a total of 7,328 bus accidents occurred in Malaysia. Among the types of buses, express buses are the highest involved in accidents compared to other types of buses such as excursion, school bus and minibus, as shown in Figure 2 [5]. This trend has shown that express bus accidents remains a major concern in Malaysia. Enhancing the perceptions on the safety of express bus is important to increase express bus ridership [6] and avoid huge losses to bus operators and eventually forcing companies to cease their operations [7].

The government and private sector have contributed with various efforts in improving the quality of service and the safety level of express buses. Many efforts have been carried out by the Road Safety Department (JKJR), Road Transport Department (JPJ), Land Public Service Agency (APAD), Malaysian 
Road Safety Research Institute (MIROS), and express bus operators. However, accident and death rates involving express buses remains at a high level. Therefore, express buses' safety aspect is one of the main concerns for passengers. The causes of express bus accidents need to be studied in detail using statistical methods. Factors that have a high impact on express bus accidents must be given attention to reduce the number of accidents. The scope of this study is limited to the operators of express bus operators. It is important to have the opinions of those who are responsible in ensuring the services provided to the passengers are safe. In addition, to date, there is no detailed analysis of express bus accidents from the perspective of express bus company operators in Malaysia. Most of the studies and statistical analysis on express bus safety that have been conducted are based on the perspective of drivers and passengers [8-10]. For example, bus accidents related to drivers, include human factor, traffic situation and working environment from the perspectives of passengers and drivers [11]. Therefore, it is important to conduct a study on the assessment of express bus safety from the perspectives of bus operators in Malaysia. This study will have an impact to reduce the number of accidents involving express bus in Malaysia and increase road safety. The assessment will be used to create a safety index of express busses in Malaysia and can be proposed to the relevant agencies and governing bodies to implement a new policy regarding the rules and regulations involving express busses in Malaysia. It is important to analyses accident causes and factors such as bus drivers' salary, level of fatigue, working environment, driving culture and behaviour. The training and recruitment of express bus drivers depends on the bus operators. Hence the importance and potential impact and contribution of this study. Beside human factors, mechanical failure are among the causes of express bus accidents. The main cause is brake failure, with $56 \%$ of total mechanical failures. Express busses are commercial and heavy load vehicles, therefore it is essential that maintenance conducted by the operators must be inspected. The perspectives obtained from this research is important in defining the guidelines for future rules and regulations for express bus operators in Malaysia.

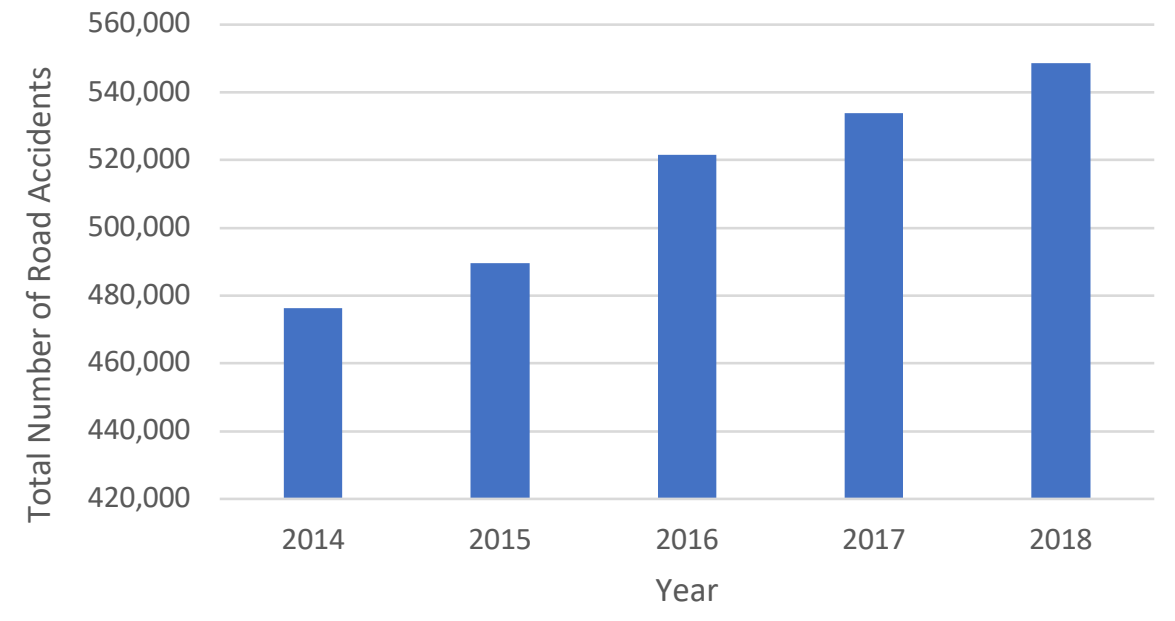

Figure 1. Number of road accidents in Malaysia for the last 5 years [3].

An improved understanding of express bus operation is important to increase the performance of bus services, safety, comfort, and to encourage the public to use express bus as their main mode of transport for long-distance travel. The quality and level of service from the operators have direct influence on the confidence of the passengers and their interest. The impact from this study is important to recover public confidence on the safety of public transportation in Malaysia. It is intended to understand perceptions of transportation operators on the safety management and drivers working conditions and culture.

Ali et al. used significance-performance analysis to identify critical factors that can provide optimal satisfaction to express bus passengers [12]. Strathman et al. studied safety risks from express bus operators' perspective by questionnaire method [13]. The results are presented by mean ranking method. Zainon et al. conducted an in-depth study on driver behaviour and highway landscape with review methods based on a survey from 39 respondents [14]. Abdullah et al. studied express bus safety from 
the passengers' perspective through a survey [15]. Meanwhile, studies on express bus safety from the perspective of express bus company operators are still limited in Malaysia [16].

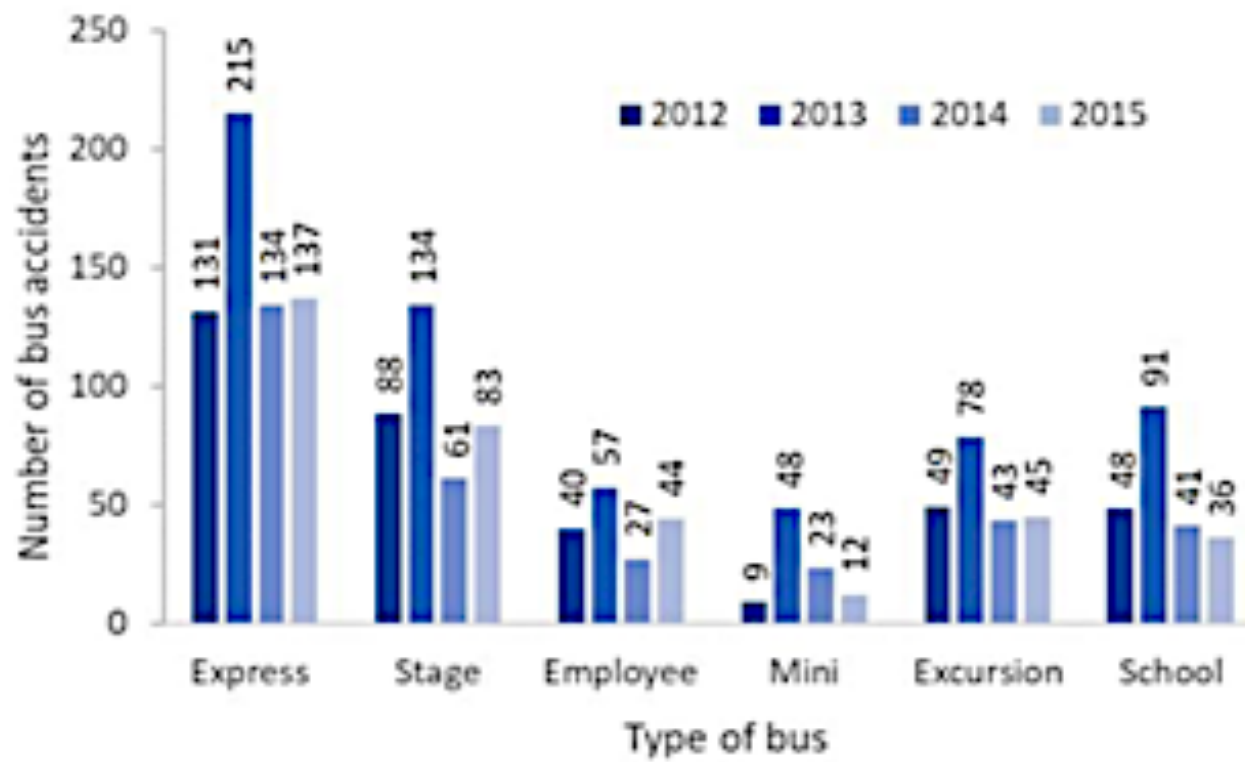

Figure 2. Bus accidents according to the different types of buses [4].

This study aims to identify the causes of express bus accidents and assess the safety of express buses with statistical analysis using IBM SPSS Statistics. This research investigates the perception of express bus operators towards express bus safety and in determining the main factors of accidents and how to increase express bus safety in Malaysia. The scope of the study is limited to the survey of express bus operators in Malaysia to obtain their perceptions on express bus safety. The expected outcome from this research is to understand the perspective of express bus operators on the safety of express bus in Malaysia and reduce the number of express bus accidents and fatalities in Malaysia. The data collected will be verified with Cronbach's Alpha reliability test and analysed by statistical method. The scope of this study is limited to express bus operators operating in Terminal Bersepadu Selatan (TBS), Bandar Tasik Selatan, and Selangor. In Malaysia, commercial buses are privately owned and operated generally by individuals and transportation firms. There are 108 express bus companies operating in the TBS listed on the official portal of the TBS management, covering journeys to all states in Malaysia. Therefore, the minimum number of respondents required for this study is 30 .

\section{Materials and methods}

Figure 3 shows a flowchart of the methodology conducted in this paper. First, factors of express bus accidents were identified based on literature review. Next, a questionnaire was developed based on the factors identified and from a previous pilot survey conducted. The targeted respondents were determined and from the results obtained, statistical analysis was conducted using IBM SPSS Statistics to assess the safety of express buses.

Operators of express bus companies operating in Terminal Bersepadu Selatan (TBS), Bandar Tasik Selatan, Selangor, as shown in Figure 4 are the target respondents for this study. The list of 108 express bus companies operating in TBS has been accessed from the official portal of TBS management. A total of 85 representatives from the express bus company operators are targeted to answer the questionnaire. A sample random sampling technique was used in the methodology of this research, where each individual is chosen by chance and each member of the population has an equal or probability, of being selected. The sample size is 85 companies based on the population out of 108 companies. The sample size calculations of Krejcie and Morgan, considering the population, were used with a linear interpolation 
method to obtain the sample size. So, 85 respondents were targeted at the initial stage, a representation of express bus companies in Malaysia. 30 is the minimum quantity required for a quantitative study [17, 18].

A first questionnaire was developed based on a pilot survey for preliminary study [5]. The questions were developed based on literature review and analysis of bus accidents from the Malaysian Road Safety Research Institute (MIROS). From the pilot study, the questionnaire is improved and divided into subcategories based on different factors.

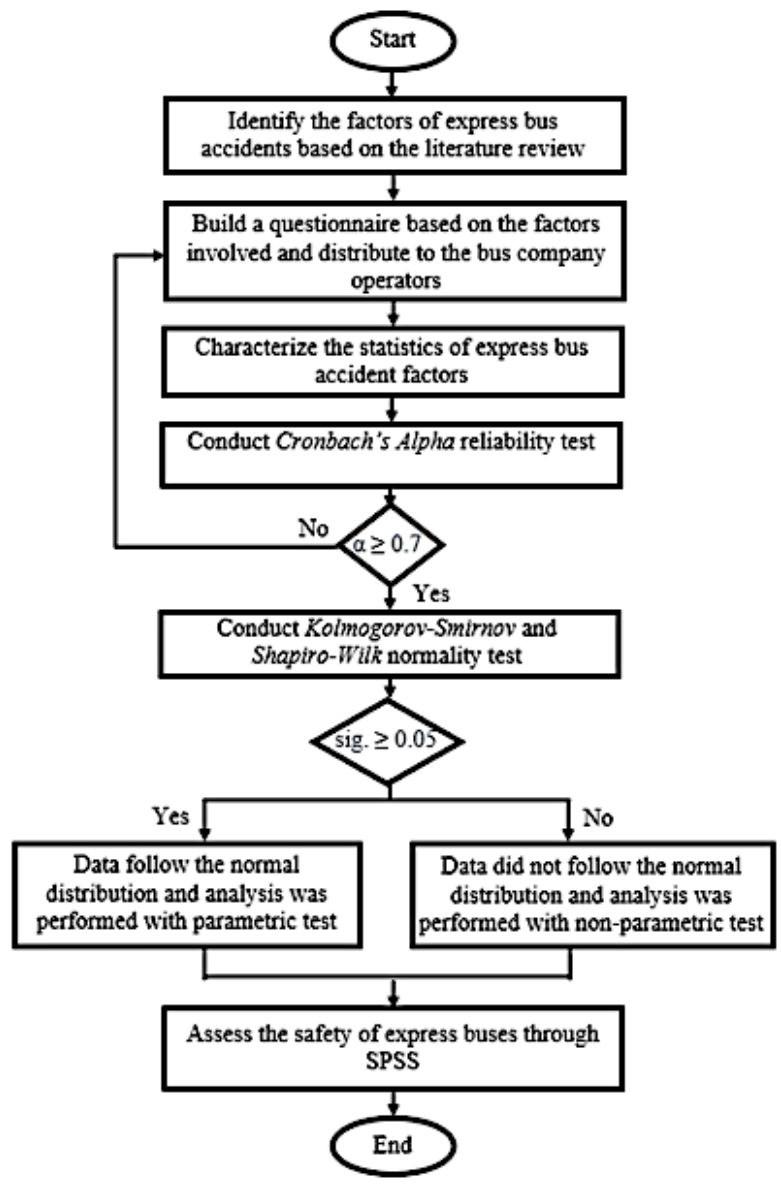

Figure 3. Flow chart of the methodology.

The questionnaire form is divided into two parts, section A and section B. Questions in section A are used to collect the demographic data of respondents, including gender, age, marital status, job position, work experience, and company name, as shown in Figure 5. The questionnaire in section B contains 24 factors that influence express bus accidents arranged according to three main categories, driver factor (8 statements), bus condition factor (8 statements), and road factor (8 statements), as show in Figure 6. The questionnaires were specially designed based on the factors of express bus accidents to improve the understanding of the questions and increase accurate analysis interpretations. Table 1 shows the factors listed in the questionnaire. 


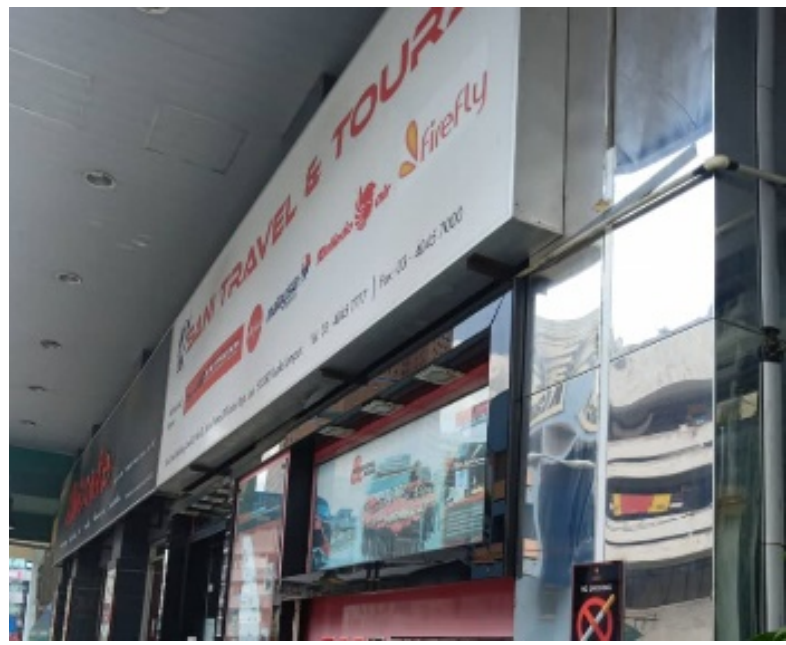

Figure 4. Survey conducted at Terminal Bersepadu Selatan.

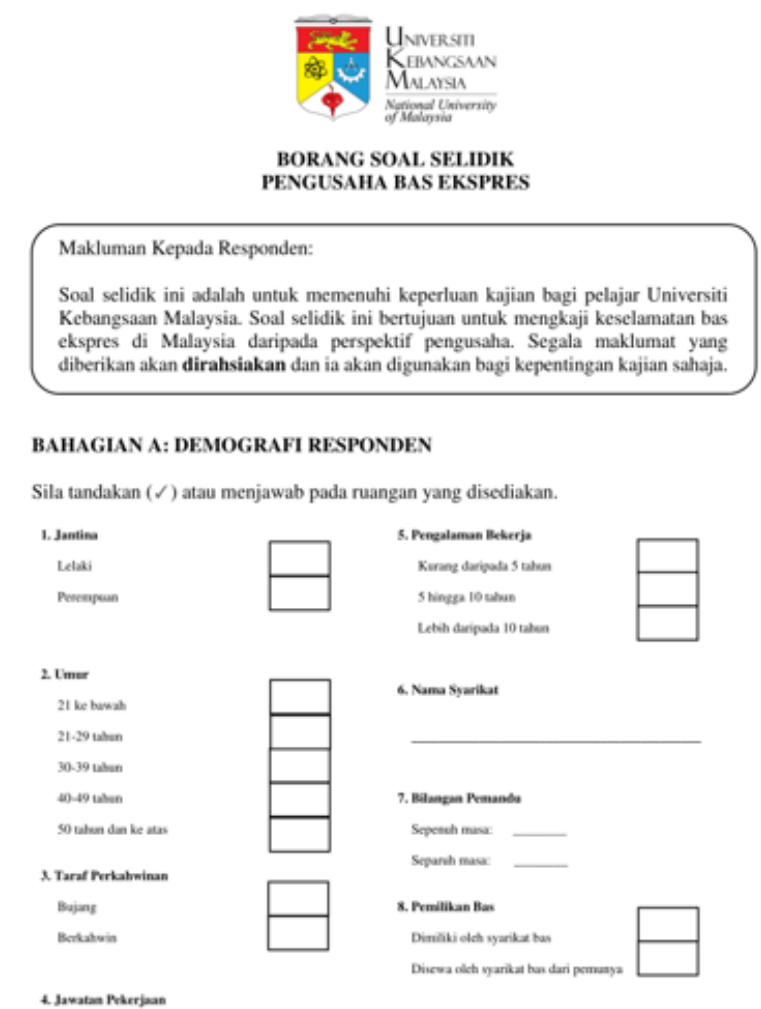

Figure 5. Survey conducted at Terminal Bersepadu Selatan.

According to a study from Adelson and McCoach, a five-point Likert scale has higher reliability compared to a four-point Likert scale [19]. A study of respondents' cognitive effort with reaction time from Chen et al. show that the five-point Likert scale is more appropriate to use from an information processing perspective [20]. The five-point Likert scale is used to answer the questions in section B as strongly disagree (1), disagree (2), satisfactory (3), agree (4), and strongly agree (5), as shown in Figure 7. 


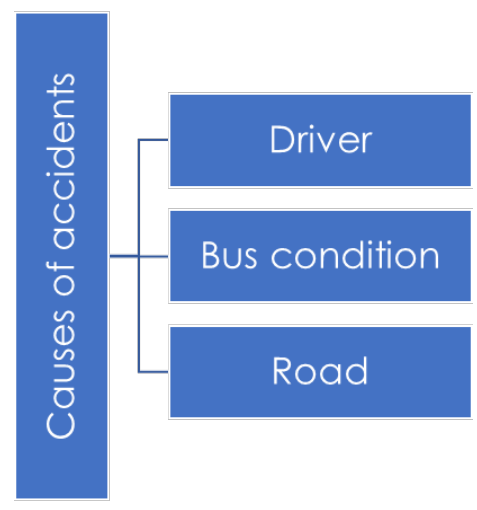

Figure 6. Three categories of express bus accident causes.

Cronbach's Alpha reliability test was developed by Lee Cronbach in 1951. This test was used to test the reliability of a set of events by studying the internal consistency and correlation between events [21-23]. The Shapiro-Wilk normality tests of a sample were used to determine whether the data collected follows normal or non-normal distribution. If the data follows the normal distribution, therefore a parametric test will be performed. Otherwise, a descriptive analysis required.

\section{BAHAGIAN B: SOALAN}

Nyatakan pandangan anda mengikut skala di bawah. Sila tandakan $(\checkmark)$ pada ruang yang disediakan.

\begin{tabular}{|c|c|c|c|c|}
\hline $\begin{array}{c}\text { Sangat } \\
\text { Tidak } \\
\text { Setuju }\end{array}$ & $\begin{array}{c}\text { Tidak } \\
\text { Setuju }\end{array}$ & $\begin{array}{c}\text { Tidak } \\
\text { Pasti }\end{array}$ & Setuju & $\begin{array}{c}\text { Sangat } \\
\text { Setuju }\end{array}$ \\
\hline 1 & 2 & 3 & 4 & 5 \\
\hline
\end{tabular}

\begin{tabular}{|c|l|c|c|c|c|c|}
\hline Bil. & FAKTOR PEMANDU & $\mathbf{1}$ & $\mathbf{2}$ & $\mathbf{3}$ & $\mathbf{4}$ & $\mathbf{5}$ \\
\hline 1 & $\begin{array}{l}\text { Pihak pengusaha memastikan pemandu bas mempunyai } \\
\text { masa rehat yang cukup dalam kerja harian. }\end{array}$ & & & & & \\
\hline 2 & $\begin{array}{l}\text { Pihak pengusaha menyediakan pemandu kedua kepada } \\
\text { pemandu semasa perjalanan yang jauh. }\end{array}$ & & & & \\
\hline 3 & $\begin{array}{l}\text { Pihak pengusaha memastikan pemandu bas mempunyai } \\
\text { kesihatan dan kesejahteraan fizikal. }\end{array}$ & & & & \\
\hline 4 & $\begin{array}{l}\text { Pihak pengusaha menyediakan gaji yang sepatutnya } \\
\text { kepada pemandu bas. }\end{array}$ & & & & \\
\hline 5 & $\begin{array}{l}\text { Pihak pengusaha memastikan pemandu bas memandu bas } \\
\text { tanpa melanggar lampu isyarat dan had laju. }\end{array}$ & & & & \\
\hline 6 & $\begin{array}{l}\text { Pihak pengusaha memastikan pemandu bas memandu bas } \\
\text { tanpa memotong kenderaan secara berbahaya. }\end{array}$ & & & & \\
\hline 7 & $\begin{array}{l}\text { Pihak pengusaha memastikan pemandu bas memandu bas } \\
\text { tanpa menekan brek secara mengejut. }\end{array}$ & & & & \\
\hline 8 & $\begin{array}{l}\text { Pihak pengusaha memastikan pemandu bas fokus semasa } \\
\text { memandu bas tanpa penggunaan telefon bimbit. }\end{array}$ & & & & \\
\hline
\end{tabular}

Figure 7. Five-point Likert scale used in the questionnaire.

\section{Results and discussion}

The respondents' demographic information is gender, age, marital status, job position, and experience in work. The express bus safety level was assessed from the perception of express bus operators. The three main factors that cause express bus accidents are driver, bus condition, and road factors.

In this study, a total of 30 respondents from 21 express bus companies participated in this survey. The bus operators involved covered bus journey throughout the whole of peninsular Malaysia. Figure 8 shows that the respondents consists of ten male and 20 female respondents. Figure 9 shows the distribution of 
the respondents based on their age. The majority of the respondents are between 21 to 29 years old, with $43 \%$. The second highest age group are between 30 to 39 years old, with $37 \%$. Figure 10(a) shows ten respondents from the management groups of the bus operators and 20 respondents among bus drivers and clerks out of a total of 30 respondents and Figure 10(b) shows the work experience of the respondents, with 15 respondents working less than five years, eight respondents working between 5 to 10 years and 7 respondents working more than 10 years.

Table 1. Factors that can cause accidents.

\begin{tabular}{|c|c|}
\hline & Factors \\
\hline C1 & Drivers have ample rest time \\
\hline $\mathrm{C} 2$ & The second driver is provided to the driver during long journeys \\
\hline C3 & Drivers have physical health and well-being \\
\hline C4 & Fair salary for the driver \\
\hline C5 & Drivers drive buses without violating traffic lights and speed limits \\
\hline C6 & Drivers drive buses without overtaking vehicles dangerously \\
\hline $\mathrm{C} 7$ & The driver drives the bus without pressing the brakes suddenly \\
\hline $\mathrm{C} 8$ & Drivers focus while driving a bus without the use of a mobile phone \\
\hline C9 & Bus maintenance is carried out periodically \\
\hline C10 & Brake function inspection is performed daily \\
\hline C11 & Tyre thread inspection is carried out daily \\
\hline C12 & Inspection of front and rear light functions is carried out daily \\
\hline C13 & Inspection of the function of the brake lights and signals is carried out daily \\
\hline C14 & Inspection of mirror wiper function is performed daily \\
\hline C15 & Make sure the windshield and side mirrors are in perfect condition \\
\hline C16 & Bus in service passed the PUSPAKOM test \\
\hline C17 & Bus travel through approved routes \\
\hline C18 & Report damage highway roads that encountered \\
\hline C19 & Report water stagnant roads that encountered \\
\hline $\mathrm{C} 20$ & Report roads with poor lighting \\
\hline $\mathrm{C} 21$ & Driver keep in the left lane when does not overtake the vehicle \\
\hline $\mathrm{C} 22$ & Report damage traffic light that encountered \\
\hline $\mathrm{C} 23$ & Driver reduces to the appropriate speed while descending steep roads \\
\hline $\mathrm{C} 24$ & Driver driving at speed within the speed limit that displayed on road signs \\
\hline
\end{tabular}

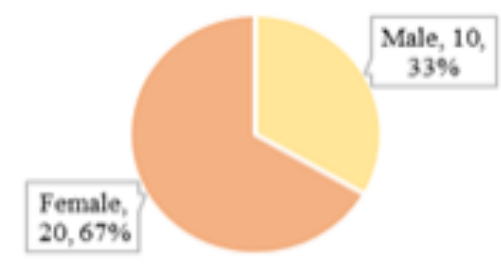

Figure 8. Gender of the respondents.

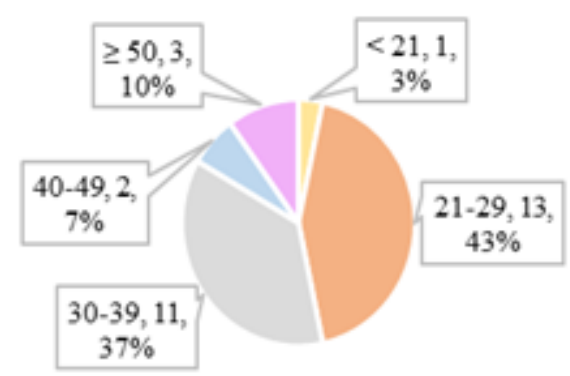

Figure 9. Age of the respondents. 

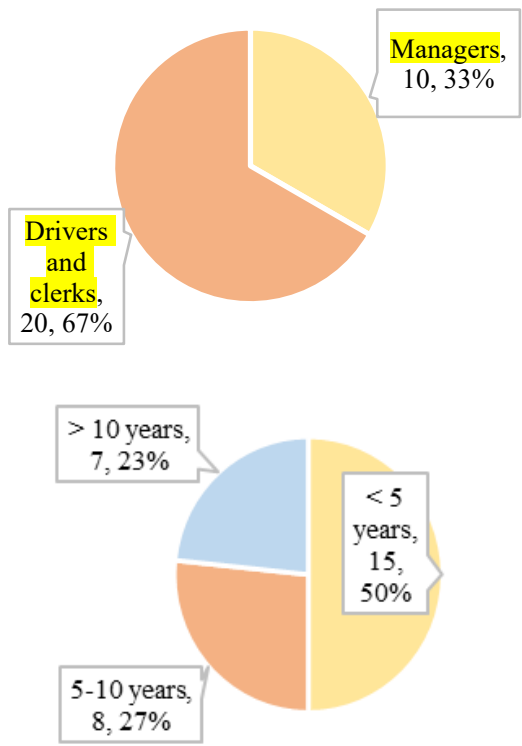

Figure 10. (a) Job position of the respondents (b) Work experience of the respondents.

Cronbach's Alpha, $\alpha$ indicates the reliability of the questionnaire. The $\alpha$ value must be at least 0.7 or above for acceptance, as presented in Table 2. The Cronbach's Alpha value for driver factor, bus condition factor, and road factor are presented in Table 3. The overall $\alpha$ value for section B's reliability is 0.931 based on the 24 accident factors in the questionnaire. Hence, the reliability level for section B is excellent.

Table 2. Acceptability based on Cronbach's alpha value.

\begin{tabular}{cc}
\hline Category & Cronbach's Alpha Value, $\alpha$ \\
\hline $0.9 \leq \alpha<1.0$ & Excellent \\
$0.8 \leq \alpha<0.9$ & Good \\
$0.7 \leq \alpha<0.8$ & Acceptable \\
$0.6 \leq \alpha<0.7$ & Questionable \\
$0.5 \leq \alpha<0.6$ & Poor \\
$\alpha<0.5$ & Not acceptable \\
\hline
\end{tabular}

Table 3. Cronbach's alpha value from the survey.

\begin{tabular}{ccc}
\hline Category & Cronbach's Alpha Value, $\alpha$ & Number of Events \\
\hline Driver Factor & 0.839 & 8 \\
Bus Condition Factor & 0.947 & 8 \\
Road Factor & 0.863 & 8 \\
Overall & 0.931 & 24 \\
\hline
\end{tabular}

Table 4, 5, and 6 presents the correlation matrices between driver, bus and road factors respectively. From the results presented, it can be observed that there is a high correlation between $\mathrm{C} 7$ (driver drives the bus without pressing the brakes suddenly) and C8 (Drivers focuses while driving a bus without the use of a mobile phone) in the driver factors. This indicates that driver etiquette highly influences driving behaviour and activities while driving, and are more likely to conduct various dangerous actions that may 
causes accidents such as late braking and illegally using mobile phones while driving. For bus factors, there is high correlation between C12 (Inspection of front and rear light functions is carried out daily) and C11 (Tyre thread inspection is carried out daily). This shows that routine bus maintenance is important and are highly related in ensuring the safety of express buses. While as for correlation for road factors, there is high relation between C19 (Report water stagnant roads that encountered) and C20 (Report roads with poor lighting) Here it is acknowledged that is it important to keep a high level of maintenance of road conditions, as they are highly related and important in reducing bus accidents.

Table 4. Correlation matrix between driver factors.

\begin{tabular}{|c|c|c|c|c|c|c|c|c|}
\hline & C1 & C2 & C3 & C4 & C5 & C6 & C7 & $\mathrm{C} 8$ \\
\hline C1 & 1.00 & .44 & .60 & .19 & .38 & .40 & .48 & .52 \\
\hline C2 & .44 & 1.00 & .64 & .12 & .50 & .27 & .27 & .36 \\
\hline C3 & .60 & .64 & 1.00 & .43 & .60 & .34 & .26 & .39 \\
\hline C4 & .19 & .12 & .43 & 1.0 & .14 & .20 & .12 & .32 \\
\hline C5 & .38 & .50 & .60 & .14 & 1.0 & .70 & .52 & .70 \\
\hline C6 & .39 & .27 & .34 & .20 & .70 & 1.00 & .55 & .73 \\
\hline C7 & .48 & .27 & .26 & .12 & .52 & .55 & 1.00 & .77 \\
\hline C8 & .52 & .36 & .39 & .32 & .70 & .73 & .77 & 1.00 \\
\hline
\end{tabular}

Table 5. Correlation matrix between bus factors.

\begin{tabular}{|c|c|c|c|c|c|c|c|c|}
\hline & C9 & C10 & C11 & C12 & C13 & C14 & C15 & C16 \\
\hline C9 & 1.00 & .44 & .60 & .19 & .38 & .40 & .48 & .52 \\
\hline C10 & .44 & 1.00 & .64 & .12 & .50 & .27 & .27 & .36 \\
\hline C11 & .60 & .64 & 1.00 & .43 & .60 & .34 & .26 & .39 \\
\hline C12 & .19 & .12 & .43 & 1.0 & .14 & .20 & .12 & .32 \\
\hline C13 & .38 & .50 & .60 & .14 & 1.0 & .70 & .52 & .70 \\
\hline C14 & .39 & .27 & .34 & .20 & .70 & 1.00 & .55 & .73 \\
\hline C15 & .48 & .27 & .26 & .12 & .52 & .55 & 1.00 & .77 \\
\hline C16 & .52 & .36 & .39 & .32 & .70 & .73 & .77 & 1.00 \\
\hline
\end{tabular}

Table 6. Correlation matrix between road factors.

\begin{tabular}{|c|c|c|c|c|c|c|c|c|}
\hline & C17 & C18 & C19 & C20 & C21 & C22 & C23 & C24 \\
\hline C17 & 1.00 & .16 & .17 & .17 & .36 & .17 & .58 & .63 \\
\hline C18 & .16 & 1.00 & .62 & .59 & .09 & .63 & .33 & .21 \\
\hline C19 & .17 & .61 & 1.00 & .93 & .57 & .90 & .24 & .20 \\
\hline $\mathrm{C} 20$ & .17 & .59 & .93 & 1.00 & .54 & .85 & .32 & .25 \\
\hline C21 & .36 & .09 & .57 & .54 & 1.00 & .59 & .26 & .23 \\
\hline C22 & .17 & .63 & .90 & .85 & .59 & 1.00 & .39 & .31 \\
\hline C23 & .58 & .33 & .24 & .32 & .26 & .39 & 1.00 & .62 \\
\hline C24 & .63 & .21 & .20 & .25 & .23 & .31 & .63 & 1.00 \\
\hline
\end{tabular}

After the determination of the Cronbach's Alpha value, the values of the Shapiro-Wilk (S-W) normality

test for every factor in section B were determined and presented in Table 7. In this study, the ShapiroWilk test is used instead of Kolmogorov-Smirnov test since the sample size is small, with 30 respondents. Referring to the significant values determined for each item with the Kolmogorov-Smirnov test and the Shapiro-Wilk test, most items have a significant value of 0 or almost 0 since the data collected for all items do not follow the normal distribution.

The normal distribution of the data obtained can be confirmed by conducting Shapiro-Wilk tests. If the significant values generated through these two tests are equal to or greater than 0.05 , it means the existence of a normal distribution of the data, as presented in Table 8. Thus, it can be concluded that the data collected does not meet the normal distribution, hence non-parametric tests are suitable for further analysis. 
Table 7. Significant values of K-S and S-W test.

\begin{tabular}{cc}
\hline Factor & Kolmogorov-Smirnov \\
\hline C1 & 0.000 \\
C2 & 0.000 \\
C3 & 0.000 \\
C4 & 0.000 \\
C5 & 0.000 \\
C6 & 0.000 \\
C7 & 0.000 \\
C8 & 0.000 \\
C9 & 0.000 \\
C10 $11 ~$ & 0.000 \\
C12 & 0.000 \\
C13 & 0.000 \\
C14 & 0.000 \\
C15 & 0.007 \\
C16 & 0.000 \\
C17 & 0.000 \\
C18 & 0.000 \\
C19 & 0.000 \\
C20 & 0.000 \\
C21 & 0.000 \\
C22 & 0.000 \\
C23 & 0.009 \\
C24 & 0.000 \\
\end{tabular}

Table 8. Significance of Shapiro-Wilk values.

\begin{tabular}{cc}
\hline Kolmogorov-Smirnov and Shapiro-Wilk values & Normality \\
\hline Significant $\geq 0.05$ & Normal distribution \\
Significant $<0.05$ & Non normal distribution \\
\hline
\end{tabular}

Based on the results of the Shapiro-Wilk (S-W) normality test, a descriptive statistic must be used for further analysis, as shown in Table 9. All questions listed in the questionnaire use positive meaning factors, which are the factors that can prevent the occurrence of accidents. Therefore, factors with the lowest mean value are significant contributors to express bus accidents. The mean values for each item and each factor were calculated to characterize the statistics of express bus accident factors. Furthermore, the overall mean value was also calculated to assess the overall safety of the express bus. In the driver category, bus driver salary has the lowest mean value of 4.10 , which indicates as the major contributor to the driver factor. Bus operators ensuring that bus drivers drive sudden breaking and ensuring that bus drivers focus while driving the bus without the use of mobile phones also have a low mean value of 4.27 and 4.33 .

Bus operators ensuring that the inspection of the brake function is carried out daily showed a low mean value of 3.87, resulting as the major contributor in the bus condition category. The following factors are bus operators ensuring that the inspection of tire thread and wipers are carried. These issues are an effective subfactor to the bus condition factor and bus operators should focus to improve on.

In the road factor category, bus operators reported that damaged roads and a lack of lighting faced by the driver has the lowest mean value of 3.40. This is the major contributor to the road factors that lead to express bus accidents. In addition, the operator also reported the stagnant water on roads and malfunctioning traffic lights as a factor of accidental causes. These factors are essential in reducing express bus accidents and need to be addressed to increase express bus safety.

Once the mean values of all the events and factors contained in the questionnaire were calculated, it was found that the mean value for express bus safety from the perspective of express bus company operators is 4.26 . Table 10 shows the descriptive statistics for each category in Section B. 
Table 9. Descriptive statistics analysis for each factor.

\begin{tabular}{ccccccc}
\hline Factor & Event & Range & Minimum & Maximum & Mean & Standard Deviation \\
\hline \multirow{5}{*}{ Driver } & C1 & 2 & 3 & 5 & 4.63 & 0.615 \\
& C2 & 2 & 3 & 5 & 4.80 & 0.484 \\
& C3 & 2 & 3 & 5 & 4.60 & 0.621 \\
& C4 & 3 & 2 & 5 & 4.10 & 0.923 \\
& C5 & 2 & 3 & 5 & 4.57 & 0.626 \\
& C6 & 2 & 3 & 5 & 4.43 & 0.679 \\
C7 & 2 & 3 & 5 & 4.27 & 0.691 \\
Bus Condition & C8 & 2 & 3 & 5 & 4.53 & 0.774 \\
& C9 & 3 & 2 & 5 & 4.43 & 0.860 \\
& C10 & 3 & 2 & 5 & 4.13 & 0.900 \\
& C11 & 3 & 2 & 5 & 4.13 & 0.887 \\
& C12 & 3 & 2 & 5 & 4.20 & 0.887 \\
& C13 & 3 & 2 & 5 & 4.20 & 0.937 \\
& C14 & 3 & 2 & 5 & 3.87 & 0.794 \\
C15 & 3 & 2 & 5 & 4.30 & 0.718 \\
& C16 & 3 & 2 & 5 & 4.63 & 0.563 \\
& C17 & 2 & 3 & 5 & 4.60 & 1.040 \\
& C18 & 3 & 2 & 5 & 3.87 & 0.037 \\
& C19 & 4 & 1 & 5 & 3.57 & 1.093 \\
& C20 & 4 & 1 & 5 & 4.40 & 0.681 \\
& C21 & 4 & 1 & 5 & 3.67 & 0.568 \\
\hline
\end{tabular}

Table 10. Descriptive statistics for each category.

\begin{tabular}{cccccc}
\hline & Range & Minimum & Maximum & Mean & Standard Deviation \\
\hline Driver & 2.00 & 3.00 & 5.00 & 4.4917 & .45832 \\
Bus & 2.75 & 2.25 & 5.00 & 4.2375 & .72394 \\
Road & 2.25 & 2.75 & 5.00 & 4.0542 & .61910 \\
Total & 2.04 & 2.96 & 5.00 & 4.2611 & .49675 \\
\hline
\end{tabular}

Figure 11 presents an overview of the results and discussions from this paper. First, the reliability test conducted obtained a Cronbach's Alpha coefficient of 0.91 , which shows excellent reliability Second, the values obtained from the Shapiro-Wilk (S-W) normality is less than 0.05 , this indicates that the data is a non-normal distribution, hence descriptive analysis must be used. From the mean values, the important factors influencing express bus safety are determined. Factors that are most important for bus drivers are fair salaries for the bus drivers and driver etiquette, for example sudden braking and not using mobile phones during driving. Factors that are most important related to bus conditions are the need for daily inspections of brakes, lights, tyres and wipers. These parts must be routinely inspected and well maintained to avoid accidents. Road conditions also influence bus safety, from the survey conducted, it is important to ensure reporting of road conditions, such as damaged highways, stagnant water, poor road lighting and broken traffic lights. From the perspectives of the bus operators, these aspects must be inspected to reduce the number of express bus accidents in Malaysia and improve safety. Better safety will increase in daily ridership of express bus and in return better profits for bus operators and ensure less casualties of innocent lives of passengers.

From the analysis, it can be observed the important roles of the express bus operators in increasing express bus safety in Malaysia. Driver salaries are set by the bus companies and it is important to have a well-structured salary scheme and salary increase to motivate and reward the driver based on their performance. A better salary structure will have a direct influence on the safety on the express bus. Hence this proves the importance of the role of the express bus operators on the direct influence of bus 
safety. Bus operators also can influence the driving behaviour of the drivers. Regular trainings are required to maintain high-quality performance and motivation of the drivers.

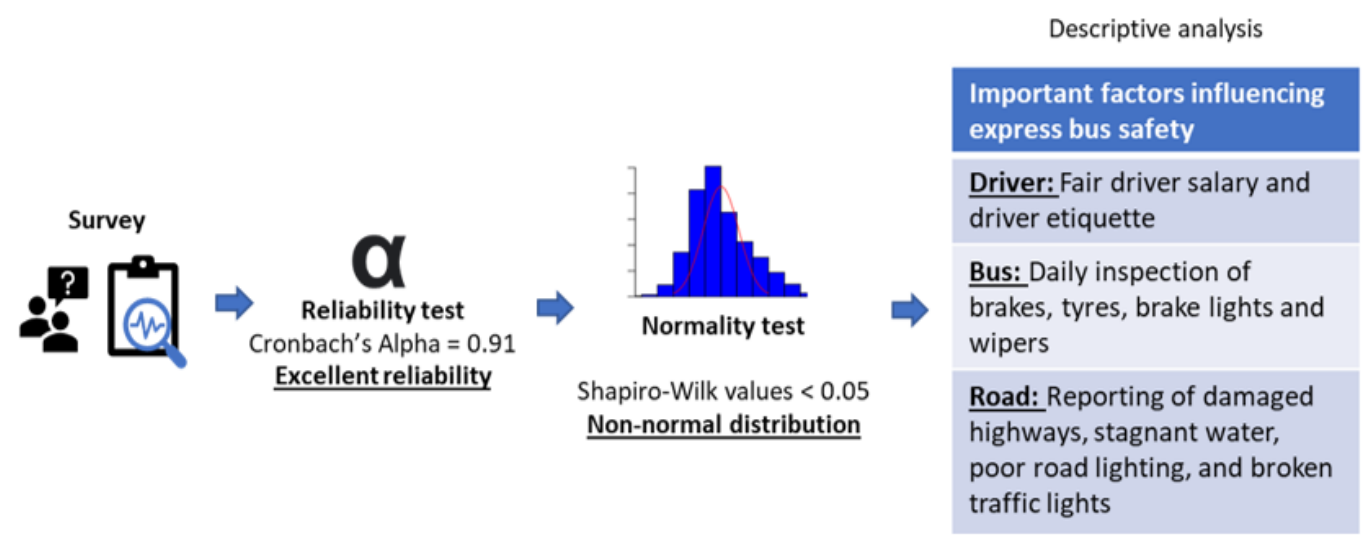

Figure 11. Overview of the analysis from the survey.

In terms of bus conditions, the inspection of the brakes, tyres, brake lights and wipers must be conducted frequently. It is interesting to note that bus operators' perspectives on these factors, as it is in agreement with the findings in the literature on the important factors related to bus conditions and its safety. Besides bus operators', relevant bodies also play a role in ensuring the safety of express buses as they manage the road conditions. It is essential to maintain high quality roads, avoid stagnant water, increase lighting and avoid non-functioning traffic lights. Hence, the data from the findings in the paper can play an important role for the related governing policies in maintaining the safety of the road conditions and play their part in the reduction of express bus accidents in Malaysia.

\section{Conclusions}

This paper is intended to understand perceptions of transportation operators on the safety management and drivers working conditions and culture. Driver, bus condition, and roads are the factors that influence express bus accidents. From these factors, road factor is the main contributor to express bus accidents from express bus operators' perspectives. However, other express bus accident subfactors such as driver factors and bus condition factors should also be considered and improved in reducing the rate of express bus accidents. Therefore, effective initiatives and approaches need to be taken to address and overcome this problem. The study also found that the general safety level of express bus was from express bus operators' perspectives is of satisfactory level. This study helped understand the perspective of express bus operators on the safety of express bus in Malaysia and determine the important factors related to express bus safety and reduce the number of express bus accidents.

Previous research only investigated the perspectives of the passengers. Therefore, this study is significant in determining the perception of express bus operators towards express bus safety and in discovering the main factors of accidents. It will have an important impact in reducing express bus accidents in Malaysia and increasing public confidence in the safety and daily use of express bus in Malaysia and increasing the use of public transport. This will play an important role in reducing the carbon emissions in Malaysia towards less air pollution by promoting public transport instead of the use of private cars for long-distance travels. The data from the analysis in this paper helps to understand the perspectives of express bus operators on the safety of express bus in Malaysia and reduce the number of accidents and fatalities in Malaysia. The findings will be used by various agencies and regulating bodies in improving the current policies and implementation, as well as keep up to date with the current technology in the Industry Revolution 4.0 era. New safety index and real-time updates can be generated 
and developed from the data obtained from this paper. The quality and level of service from the operators have direct influence on the confidence of the passengers and their interest and will increase the public confidence on the safety of public transportation in Malaysia.

\section{Conflicts of interest}

The authors declare that there is no conflict of interest regarding the publication of this paper.

\section{Funding statement}

The authors would like to thank Universiti Kebangsaan Malaysia for funding this research under the project GUP-2020-019.

\section{References}

[1] Minhans, A. and Moghaddasi, A., 2013. Transport Cost Analysis of City Bus and Private Car Usage in Johor Bahru, Malaysia. Jurnal Teknologi, 65(3).

[2] Filianie Aziz. A Study on Service Quality in Relations Towards Customer Satisfaction Among Express Bus Customer in Kuantan, 2013, Universiti Malaysia Pahang.

[3] Transport Statistics Malaysia. 2018. Ministry of Transport Malaysia. http://www.mot.gov.my/

[4] JKJR. 2018. Buku Statistik Keselamatan.

[5] A.H. Azman, S.S.K. Singh, W.G.W. Aizon, H. Hishamuddin, M.R.M. Yazid, S. Abdullah, A.K. Ariffin, D. A. Wahab, R. Atiq,,M.S. Solah, A. Hamzah, 2018. The Needs to Establish an Integrated Safety System for Express Bus, International Journal of Engineering \& Technology, 7 (4.36):1537-154.

[6] Pung, J.C. and Mokhtar, S., 2019. Assessing Perceptions Towards Public Bus Service Among the Car Users in Iskandar Malaysia. International Journal of Built Environment and Sustainability, 6(1-2), pp.23-30.

[7] Yukawa, S., Ladin, M.A. and Rahmat, R.A.A.O., 2014. Public Transport System in Local City and Rural Area: Comparative Study Between Malaysia and Japan. Jurnal Teknologi, 69(6).

[8] J. M. Diah and N. Q. A. Hamidun. 2018. The methodology review of traffic safety monitoring by using video recording for express bus in Malaysia, 2018 IEEE 14th International Colloquium on Signal Processing \& Its Applications (CSPA), Batu Feringghi, pp. 1-6.

[9] Bachok, S., Osman, M.M. and Abdullah, M.F., 2018. Profiling intercity bus drivers of Malaysia. Planning Malaysia, 16(5).

[10] Kim, H., Jang, T.W., Kim, H.R. and Lee, S., 2018. Evaluation for fatigue and accident risk of Korean commercial bus drivers. The Tohoku Journal of Experimental Medicine, 246(3), pp.191-197.

[11] Rohani, M.M., Nawi, N.N.M., Daniel, B.D., Buhari, R. and Ambak, K., 2018. An Overview of Bus Drivers and Accident Involvement. Advanced Science Letters, 24(11), pp.8683-8686.

[12] Ali, Z. M., Ismail, M., Suradi, N. R. M. \& Ismail, A. S. 2009. Importance-performance analysis and Customer Satisfaction Index for express bus services. 2009 World Congress on Nature and Biologically Inspired Computing, NABIC 2009 - Proceedings. 2005: 590-595.

[13] Strathman, J. G., Kwon, S.-M. \& Callas, S. 2013. Bus Operator Perceptions of Safety Risks. Annual Meeting of the Transportation Research Board (July).

[14] Zainon, M., Shah, M. Z., Chiroma, M. A. \& Kafi, M. A. 2018. Monotonous Driving Environment along Highway and Driver Behaviour in Malaysia: A Review Open Access. Journal of the Society of Automotive Engineers Malaysia 2(1): 60-74.

[15] Abdullah, S., Singh, S. S. K., Azman, A. H., Yazid, M. R. M., Hishamuddin, H., Ghopa, W. A. W., Shahrir, A. H., et al. 2020. Assessing the safety behaviour of the bus express driving condition from the passengers' perspective. International Journal of Integrated Engineering 12(5): 27-33.

[16] Minhans, A., Shahid, S. \& Ahmed, I. 2014. An investigation into qualitative differences between bus users and operators for intercity travel in Malaysia. Jurnal Teknologi 70(4): 71-81.

[17] Coelho Sales, N., Gurgel Carlos da Silva, M. \& Maia Pinto, F. J. 2014. Core competencies developed by managers of family health centers TT. Rev. bras. promoç. Saúde, 27(3): 389-397.

[18] Saragih, L. L., Simarmata, E., Aloina, G., Tarigan, U. P. P., Ramadhani, V. B. \& Ginting, S. E. F. 2020. Product development of canned fish using SWOT and quality function deployment (QFD). Recent Progress On: Mechanical, Infrastructure And Industrial Engineering: Proceedings of International Symposium on Advances in Mechanical Engineering (Isame): Quality in Research 2019 2227(May): 040017.

[19] Adelson, J. L. \& McCoach, D. B. 2010. Measuring the mathematical attitudes of elementary students: The effects of a 4-point or 5-point likert-type scale. Educational and Psychological Measurement 70(5): 796-807. 
[20] Chen, X., Yu, H. \& Yu, F. 2015. What is the optimal number of response alternatives for rating scales? From an information processing perspective. Journal of Marketing Analytics 3(2): 69-78.

[21] Taber, K. S. 2018. The Use of Cronbach's Alpha When Developing and Reporting Research Instruments in Science Education. Research in Science Education 48(6): 1273-1296.

[22] Tavakol, M. \& Dennick, R. 2011. Making sense of Cronbach's alpha. International Journal of Medical Education 2: $53-55$.

[23] Vaske, J. J., Beaman, J. \& Sponarski, C. C. 2017. Rethinking Internal Consistency in Cronbach's Alpha. Leisure Sciences 39(2): 163-173. 